\title{
EVALUASI KINERJA \\ GURU FISIKA, BIOLOGI DAN KIMIA SMA YANG SUDAH LULUS SERTIFIKASI
}

\author{
Yusrizal, Soewarno S, Zarlaida Fitri
}

Fakultas Keguruan dan Ilmu PendidikanUniversitas Syiah Kuala

J1. T. Nyak Arief Darussalam Banda Aceh 23111

yusrizal_fkipunsyiah@yahoo.co.id

\begin{abstract}
Abstrak
Penelitian ini bertujuan (1) mengembangkan instrumen evaluasi kinerja guruyang valid dan reliabel, (2) mengevaluasi kinerja guru Fisika, Biologi, dan Kimia SMA yang sudah tersertifikasi/menerima tunjangan profesi. Populasi penelitian yaitu seluruh guru Fisika, Biologi dan Kimia SMA tersertifikasi/penerima tunjangan profesi yang berada di Kota Banda Aceh, Kabupaten Aceh Besar dan Kabupaten Pidie.Validitas konstruk instrumen yang dikembangkan dibuktikan melalui analisis faktor, dan reliabilitasnyadiestimasi dengan rumus alpha Cronbach. Analisis tingkat kinerja ditentukan dengan persentase. Hasil penelitian menunjukkan: (1) instrumen yang dikembangkan terdiri atas 33 butir pernyataan, dan memiliki koefisien reliabilitas konsistensi internal sebesar 0,953 ; (2) kinerja guru Fisika, Biologi, dan Kimia SMA yang sudah lulus sertifikasi dan sudah menerima tunjangan belum seluruhnya berkinerja tinggi; (3) kinerja guru Kimia relatif lebih baik dari pada kinerja guru Biologi dan guru Fisika.
\end{abstract}

Kata kunci: evaluasi, kinerja guru, validitas, reliabilitas 


\title{
AN EVALUATION OF THE PERFORMANCE OF CERTIFIED SCIENCE TEACHERS (PHYSICS, CHEMISTRY AND BIOLOGY) OF SENIOR HIGH SCHOOLS
}

\author{
Yusrizal, Soewarno S, Zarlaida Fitri
}

Teacher Training and Education Faculty of Syiah Kuala University

Jl. T. Nyak Arief Darussalam Banda Aceh 23111

yusrizal_fkipunsyiah@yahoo.co.id

\begin{abstract}
This study was aimed at (1) developing a valid and reliable performance evaluation instruments for teachers, and (2) evaluating the level of Physics, Biology and Chemistry teachers of senior high schools who have been certified and received theprofession allowance. The population of this study included all certified Physics, Biology and Chemistry teachers of senior high schools who have received profession allowance in Banda Aceh, Aceh Besar, and Pidie. The construct validity of the instrument developed was assessed through factor analysis, and the reliability was estimated by using Cronbach's Alpha formula. The level of teachers'performance was analyzed by the percentage. The result of the research shows that (1) the instrument developed consists of 33 items, and has an internal consistency reliability coefficient of 0,953 , (2) not all certified high school teachers who have received profession allowance and teach Physics, Biology and Chemistry show high performance, and (3) the performance of Chemistry teachers is relatively higher than that of Physics and Biology teachers.
\end{abstract}

Keywords:evaluation, teachers'performance, validity, reliability 


\section{Pendahuluan}

Pada tataran nasional mutu pendidikan Aceh berada pada ranking 23 dari 33 provinsi di Indonesia (HDI-UNDP dalam Harian Serambi Indonesia, 16/11/2007). Nilai Ujian Nasional (UN) SMA/MA tahun 2008/2009 serta tingkat kelulusan siswa yang berasal dari SMA/MA Aceh pada beberapa ujian saringan masuk perguruan tinggi negeri menunjukkan bah-wa mutu pendidikan Aceh masih rendah. Salah satu aspek yang diduga penyebab masih rendahnya mutu pendidikan Indonesia, khususnya di Aceh adalah rendahnya kinerja dari guru, karena guru merupakan agen dan pengelola pembelajaran di kelas

Tanpa ada kinerja guru yang berkualitas, semua upaya untuk membenahi pendidikan akan kandas. Kurikulum yang baik, perpustakaan yang lengkap, laboratorium canggih, ketersediaan komputer dan internet nyaris tidak ada artinya untuk memperbaiki mutu pendidikan bila guru-gurunya tidak bermutu dan tidak mencintai profesinya. (Wisudo dan Permanasari, Kompas 21/02/2006).

Salah satu upaya pemerintah untuk meningkatkan kualitas pendidikan yang sudah dan sedang dilakukan adalah menerbitkan Undang-Undang Nomor 14 Tahun 2005 Tentang Guru dan Dosen. Undang-Undang tersebut dan Peraturan Pemerintah Nomor 74 Tahun 2008 tentang Guru mengamanatkan bahwa guru wajib memiliki kualifikasi akademik, kompetensi, dan sertifikat pendidik. Sehubungan dengan hal tersebut, diterbitkan Peraturan Menteri Pendidikan Nasional (Permendiknas) Nomor 10 Tahun 2009 tentang Sertifikasi bagi guru dalam jabatan.

Melalui UU Nomor 14 Tahun 2005 tentang Guru dan Dosen tersebut, pemerintah telah menempatkan guru sebagai tenaga profesional yang dibuktikan dengan sertifikat pendidik. Untuk implementasinya, pemerintah mulai tahun 2006 sudah memilih sejumlah guru untuk disertifikasi melalui penilaian portofolio oleh LPTK yang telah ditunjuk. Untuk Provinsi Aceh, telah ditetapkan FKIP Unsyiah sebagai lembaga penilaian portofolio para guru. Bagi guru yang portofolionya belum mencapai skor minimal kelulusan, diharuskan mengikuti Pendidikan dan Latihan Profesi Guru (PLPG). Kepada guru yang sudah memperoleh sertifikat pendidik pemerintah 
memberikan tunjangan profesi setara dengan 1 (satu) kali gaji pokok guru yang bersangkutan.

Hingga tahun 2008, sudah lebih 4000 orang guru dalam Provinsi Aceh dinilai portofolionya oleh LPTK Unsyiah, di samping melalui Pendidikan dan Latihan Profesi Guru (PLPG), diantaranya terdapat sejumlah guru SMA yang mengajar mata pelajaran Fisika, Biologi, dan Kimia. Setelah guru dinyatakan lulus sertifikasi dan dibayar tunjangan profesinya maka secara teori kinerja guru tersebut akan membaik. Namun, tidak ada suatu jaminan bahwa jika seorang guru yang sudah mendapatkan tambahan penghasilannya lantas serta merta kinerjanya tinggi.

Terkait dengan permasalahan tersebut tujuan penelitian ini adalah: (1) mengembangkan sebuah alat ukur (instrumen) evaluasi kinerja guru-guru pengajar mata pelajaran Fisika, Biologi, dan Kimia SMA yang sudah lulus sertifikasi/menerima tunjangan profesi yang valid dan reliabel, (2) mengevaluasi tingkat kinerja guru-guru SMA yang mengajar mata pelajaran Fisika, Biologi, dan Kimia yang sudah lulus sertifikasi/menerima tunjangan profesi yang berada di Kota Banda Aceh, Kabupaten Aceh Besar, dan Kabupaten Pidie.

Kinerja guru yang sudah lulus sertifikasi, khususnya kinerja yang terkait dengan proses belajar mengajar sangat erat kaitannya dengan usaha meningkatkan mutu pendidikan. Kualitas proses dan hasil pendidikan terletak pada kinerja perilaku mengajar para guru. Mutu hasil belajar sebagai indikator mutu pendidikan ditentukan oleh kualitas belajar siswa yang terwujud melalui proses interaksi pengajaran yang dikreasikan oleh kinerja guru.

Informasi tingkat kinerja guru-guru SMA yang sudah lulus sertifikasi khususnya guru-guru yang mengajar kelompok mata pelajaran IPA, dapat menjadi bahan masukan dan pertimbangan kepada Departemen Pendidikan Nasional dalam menetapkan kebijakan lebih lanjut yang terkait dengan penyempurnaan pelaksanaan sertifikasi guru, baik yang dilaksanakan melalui penilaian fortofolio maupun kelulusan sertifikasi melalui Pendidikan dan Latihan Profesi Guru (PLPG). Informasi tingkat kinerja guru-guru ini juga menjadi bahan masukan kepada Dinas Pendidikan Provinsi Aceh dan 
Dinas Pendidikan Kabupaten/Kota dalam melakukan pengembangan kualitas guru, terutama yang menyangkut kompetensi guru.

Bagi pihak sekolah, informasi tingkat kinerja guru dapat dijadikan sebagai dasar meningkatkan dan memacu guru dalam berkreativitas untuk meningkatkan kemampuan dan keterampilannya. Bagi guru bersangkutan, informasi tingkat kinerjanya dapat dijadikan sebagai bahan introspeksi diri, sehingga guru sebagai individu dapat memperbaiki diri sendiri untuk meningkatkan prestasi secara optimal dalam melaksanakan tugas profesionalnya. Guru-guru yang berkinerja tinggi akan membelajarkan siswa sehingga dapat melahirkan lulusan bermutu. Guru-guru berkinerja tinggilah pada gilirannya yang akan mengangkat mutu pendidikan.

Evaluasi merupakan suatu proses keputusan manusia untuk menyimpulkan suatu hasil pengujian/pengukuran (Anderson,et.al,1975:136). Gronlund (1985:5) mengemukakan bahwa: "Evaluation be defined as the systematic process of collecting, analizing, and interpreting information to determine the extent to which pupils are achieving instructional objectives" .Evaluasi dapat diartikan sebagai suatu proses yang sistematis untuk mengumpulkan, menganalisis dan menafsirkan informasi untuk menentukan sejauh mana tingkat pencapaian terhadap tujuan-tujuan yang telah ditetapkanJadi, evaluasi adalah suatu proses pengumpulan informasi dan penentuan pengambilan keputusan yang didasarkan pada kriteria atau patokan-patokan tertentu untuk mencapai tujuan.

Maier sebagaimana dikutip oleh As'ad (1995:46) mengatakan bahwa kinerja merupakan kesuksesan seseorang dalam melaksanakan suatu pekerjaan.Hal ini menjelaskan bahwa kinerja adalah hasil yang dicapai seseorang menurut ukuran yang berlaku untuk pekerjaan yang bersangkutan. Kinerja seseorang dapat terlihat dari aktivitasnya dalam melaksanakan pekerjaan sehari-hari. Aktivitas ini menggambarkan bagaimana ia berusaha dalam mencapai tujuan yang telah ditetapkan.

Kinerja merupakan perilaku yang ditunjukkan seseorang selama menjalankan pekerjaan. Dalam arti kemampuan kerja atau prestasi kerja, kinerja merupakan tingkat keberhasilan di dalam melaksanakan tugas serta kemampuan untuk mencapai tujuan yang telah ditetapkan (Donelly and Gibson, 1985:57). Menurut Carroll, (1977:129) kinerja merupakan hasil usaha, 
sedangkan tingkatan kinerja secara relatif diukur menggunakan standar yang disebut produktivitas. Dengan kata lain,kinerja seseorang terkait dengan bagaimana ia melakukan tugas dan hasil yang telah dicapainya.

Kinerja guru secara signifikan berkorelasi dengan motivasinya. Prawirosentono (1999:193) mengemukakan bahwa kinerja seseorang bergantung pada kemampuan dan motivasi. Demikian pula yang dikatakan Mitchell (1982:159) bahwa kinerja merupakan fungsi dari faktor kemampuan dan motivasi. Ini artinya jika ada perubahan pada salah satu faktor itu maka secara langsung akan mempengaruhi kinerja yang bersangkutan. Oleh karena itu, seorang guru yang sudah memperoleh tunjangan profesi, semestinya kinerja guru tersebut meningkat.

Bila dikaitkan dengan guru maka kinerja guru tidak lain adalah kemampuan guru untuk menampilkan atau mengerjakan tugas guru. Guru mempunyai tugas untuk mendidik, mengajar, dan melatih. Mendidik berarti meneruskan dan mengembangkan nilai-nilai hidup, mengajar berarti meneruskan dan mengembangkan pemahaman siswa terhadap ilmu pengetahuan dan teknologi, sedangkan melatih berarti mengembangkan keterampilanketerampilan pada siswa (Usman, 2003;7).

Menurut Reddy (1998:122), kinerja guru lebih menekankan pada konsep Dunkin dan Biddle yang variabel proses lebih penting dari pada variabel produk. Variabel proses merujuk pada tingkah laku guru dalam mengajar dan atau melatih mulai dari merencanakan, mempersiapkan dan melaksanakan pembelajaran di dalam kelas.

Dalam penelitian ini yang dimaksud dengan kinerja guru Fisika, Biologi, dan Kimia SMA adalah aktivitas guru SMA ketiga pelajaran tersebut dalam melaksanakan pembelajaran dan dapat diamati oleh siswa, yang mencakup (1) strategi pembelajaran, (2) penguasaan materi, (3) pengelolaan kelas. (4) komunikasi guru dengan siswa, (5) teknik mengajar, dan (6) penilaian hasil belajar siswa (Sumiyati, 2005:4;Soekartawi, 1995:3738; Riyanto, 2003:47).

Salah satu pihak yang dapat melakukan penilaian terhadap kinerja guru adalah siswa. Miller (1975:30) mengemukakan terdapat bukti yang menunjukkan bahwa siswa-siswa dapat menilai pengajaran gurunya secara adil dan secara perspektif.Karenanya, dalam penelitian ini, yang menilai 
kinerja guru adalah siswa SMA yang terdapat guru tersertifikasi/telah menerima tunjangan profesi.Untuk mengukur kinerja perlu didefinisikan terlebih dahulu apa itu kinerja. Untuk melahirkan definisi kinerja diperlukan sejumlah teori. Menurut Hadi (1986:113) jika bangunan teorinya sudah benar, maka hasil pengukuran yang menggunakan alat pengukur yang berbasis pada teori itu dipandang valid.

Kinerja adalah atribut psikologis yang tidak dapat diukur secara langsung. Menurut Suryabrata $(2000: 177)$ atribut psikologis tidak dapat diukur secara langsung, atribut psikologis hanya dapat diukur secara tidak langsung melalui respons yang dibuat oleh subjek pada waktu subjek dihadapkan kepada perangsang tertentu. Oleh karena itu, konstruk alat ukur untuk evaluasi kinerja guru dalam penelitian ini adalah kuesioner yang berisi sejumlah pernyataan yang menunjuk pada indikator-indikator yang diperkirakan atau berkorelasi dengan kinerja guru.

Instrumen evaluasi kinerja guru SMA yang mengajar kelompok mata pelajaran Fisika, Biologi, dan Kimia dalam penelitian ini menggunakan jenis skala diferensial semantik yang memiliki tujuh pilihan jawaban, yang berbentuk skala berkontinum yang masing-masing berisi keadaan tentang kemungkinan respons perasaan/sikap siswa terhadap aktivitas gurusewaktu melaksanakan kegiatan pengajaran. Dari ketujuh pilihan jawaban tersebut, responden diminta untuk memilih satu jawaban yang dianggap paling sesuai dengan apa yang dirasakannya.

Instrumen adalah suatu alat yang karena memenuhi persyaratan akademis maka dapat dipergunakan sebagai alat untuk mengukur suatu objek ukur atau mengumpulkan data mengenai suatu variabel (Muhammad\& Djaali, 2005:28). Instrumen berfungsi mengungkapkan fakta menjadi data.

Adapun langkah-langkah yang dilakukan dalam pengembangan instrumen evaluasi kinerja guru SMA yang mengajar kelompok mata pelajaran Fisika, Biologi, Kimia ini, meliputi: pertama-tama ditetapkan konstruk variabel kinerja guru yang merupakan sintesis dari sejumlah teori dan dianalisis. Kemudian konstruk tersebut dijelaskan dalam definisi konseptual dan operasional yang mencakup dimensi, indikator dari variabel kinerja guru. Kemudian dibuat butir-butir instrumen untuk mengukur indikator-indikator, diikuti validasi teoritik oleh para pakar. Selanjutnya, dilakukan ujicoba 
empiris, penentuan validitas konstruk, pengujian reliabilitas, serta pengadministrasian instrumen (Gable, 1986:170-177; Djaali dan Muljono, 2008:8185).

\section{Metode Penelitian}

Pendekatan penelitian ini dilakukan dalam dua tahap. yakni, pada tahap pertama mengembangkan instrumen evaluasi kinerja guru, dan tahap kedua melakukan penelitian terhadap guru-guru yang mengajar mata pelajaran Fisika, Biologi, Kimia SMA yang sudah lulus sertifikasi dan telah menerima tunjangan profesi. Pengembangan instrumen evaluasi kinerja guru ini dilaksanakan pada bulan 19 Maret sampai dengan 19 Juni 2009.

Adapun proses dan langkah pengembangan instrumen evaluasikinerja guru SMA yang mengajar mata pelajaran Fisika. Biologi, Kimia adalah menurut bagan alir berikut.

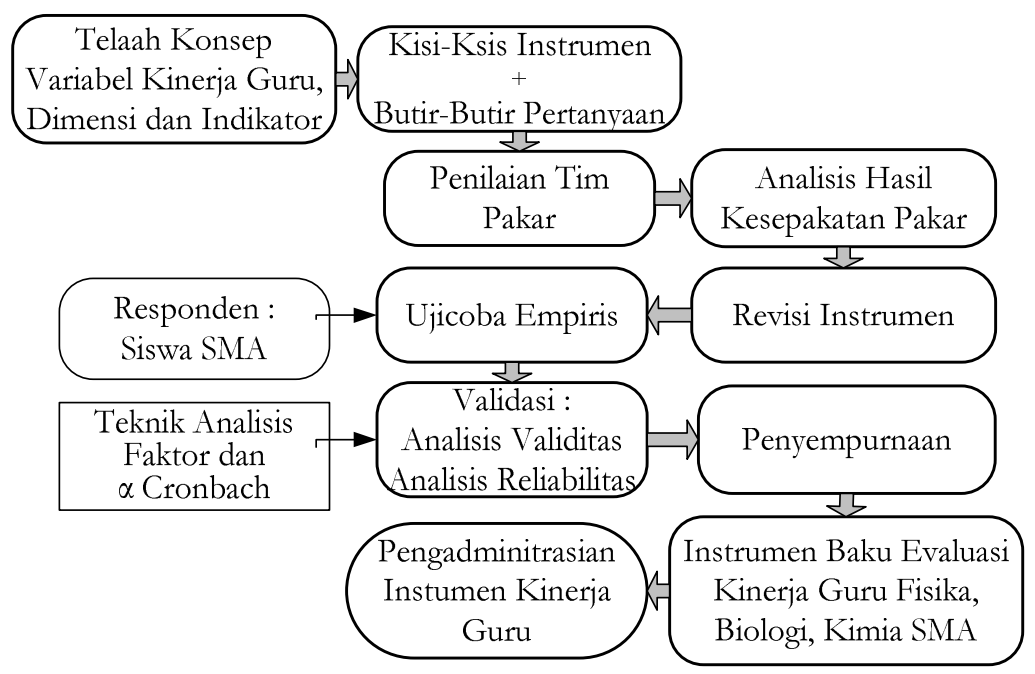

Gambar 1.Bagan Alir Pengembangan Instrumen Evaluasi Kinerja Guru SMA yang Mengajar Mata Pelajaran Fisika, Biologi, Kimia

Populasi dalam penelitian ini adalah seluruh guru SMA negeri pengajar mata pelajaran Fisika, Biologi, Kimia yang sudah lulus sertifikasi dan 
menerima tunjangan profesi. Penelitian ini memakai pendekatan populatif dengan meneliti keseluruhan guru yang menjadi anggota populasi. Dengan demikian, di dalam penelitian ini tidak diadakan sampel penelitian.

Instrumen evaluasi hasil pengembangan terdiri atas 33 butir pernyataan yang subtansi pernyataannya adalah mencakup indikator kinerja guru dalam melaksanakan proses belajar mengajar di kelas. Instrumen evaluasi kinerja guru ini dikonstruk dengan memakai skala semantik diferensial, yang memiliki tujuh pilihan jawaban, yang berbentuk skala berkontinum.

Pengumpulan data untuk mendapatkan informasi yang dibutuhkan dilakukan dengan teknik survei.Data yang didapatkan dari hasil kuesioner akan dianalisis menggunakan bantuan program Microsoft Excel.Penelitian dilaksanakan pada 20 Juni 21 Agustus 2009.

Untuk melihat tingkat/penafsiran terhadap hasil evaluasi kinerja guru-guru Fisika, Biologi, Kimia digunakan kategorisasi berdasarkan pendapat Azwar (2003:108) sebagai terlihat pada Tabel 1 sebagai berikut:

Tabel 1. Rentang Skor dan Kategori

\begin{tabular}{clc}
\hline No. & \multicolumn{1}{c}{ Rentang Skor } & Kategori \\
\hline 1 & $\mathrm{X}<(\mu-1 \sigma)$ & rendah \\
2 & $(\mu-1 \sigma) \leq \mathrm{X}<(\mu+1 \sigma)$ & sedang \\
3 & $\mathrm{X} \geq(\mu+1 \sigma)$ & tinggi \\
\hline
\end{tabular}

$\mu=1 / 2$ (skor tertinggi + skor terendah)

$\sigma=1 / 6$ (skor tertinggi - skor terendah)

\section{Hasil Penelitian dan Pembahasan}

\section{Pengembangan Instrumen}

Hasil pengujian validitas konstruk instrumen dengan menggunakan analisis faktor, didapatkan nilai KMO instrumen sebesar 0,952. Nilai ini lebih besar dari 0,50 berarti analisis faktor dapat dilanjutkan untuk menganalisis data dalam bentuk matriks korelasi (Santoso, 2003:101). Di samping, itu nilai Bartlett's test of Sphericity sebesar 5642.264 pada derajat kebe- 
basan 528 dengan taraf signifikansi $0,000(0.000<0,05)$, dengan demikian matriks korelasi yang terbentuk bukan matriks identitas, jadi analisis faktor bisa dilanjutkan. Salinan nilai KMO dan nilai Bartlett's test secara lengkap dapat dilihat pada Tabel 2 berikut.

Tabel 2.Tabel KMO and Bartlett's

\begin{tabular}{lll}
\hline \multicolumn{2}{c}{ Kaiser-Meyer-Olkin Measure of Sampling Adequacy. } & \multicolumn{1}{c}{.952} \\
\hline Bartlett's Test of Sphericity & Approx. Chi-Square & 5642.264 \\
& Df & 528 \\
& Sig. & .000 \\
\hline
\end{tabular}

Pada Tabel Total Variance Explained dari 33 butir yang dimasukkan dalam analisis faktor didapatkan nilai akar karakteristik (eigen value) di atas 1 $(\geq 1)$ ada sebanyak 6 faktor, hal ini sesuai dengan banyaknya indikator yang diestimasikan.

Hasil rotated component matrix yang dilakukan 8 putaran atau iterasi, menunjukkan tidak ada butir yang melewati muatan faktor " cut off point" lebih kecil dari $0,30(<\mathbf{0 , 3 0})$. Muatan faktor terbesar terdapat pada butir 1 sebesar 0,732 dan terkecil pada butir 23 sebesar 0,445. Dengan demikian, ke 33 butir pernyataan alam instrumen evaluasi kinerja guru yang dikembangkan adalah valid.

Reliabilitas instrumen evaluasi kinerja guru Fisika, Biologi, dan Kimia SMA dianalisis menggunakan rumus Alpha $(\alpha)$ dari Cronbach. Perhitungan terhadap 33 butir instrumen yang dilakukan dengan menggunakan bantuan program SPSS version 12.0 Windows diperolehkoefisien sebesar 0,953. Dengan demikian, dapat dinyatakan bahwa instrumen penilaian kinerja guru Fisika, Biologi, dan Kimia SMA yang dikembangkan dalam penelitian ini memiliki validitas konstruk yang baik dan reliabilitas yang sangat tinggi.

Selain itu, adanya varians muatan faktor yang dapat menjelaskan adanya varians instrumen, muatan oleh faktor pertama $41.417 \%$, kedua 4,711 $\%$, ketiga 4,530 \%, keempat 3,436 \%, kelima 3,171\%, dan keenam 3,105 
$\%$, sehingga secara kumulatif keenam faktor tersebut adalah 60,371\% variansi.

\section{Evaluasi Kinerja Guru}

Hasil analisis terhadap keseluruhan guru Fisika, Biologi, Kimia SMA yang sudah lulus sertifikasi dan telah menerima tunjangan profesinya, memperlihatkan sebanyak 77,1 \% guru tingkat kinerjanya berada dalam kategori tinggi. Ada sebanyak 22,9\% orang guru yang tingkat kinerjanya berada dalam kategori sedang. Jadi, belum semua guru pengajar Fisika, Biologi dan Kimia yang tersertifikasi/penerima tunjangan profesi memiliki kinerja yang tinggi (maksimal).

Jika dilihat berdasarkan mata pelajaran, untuk guru pengajar Fisika didapat ada 66,6\% guru fisika berada dalam kategori tingkat kinerjanya tinggi, dan 33,3\% guru fisika berada dalam kategori tingkat kinerjanya sedang.

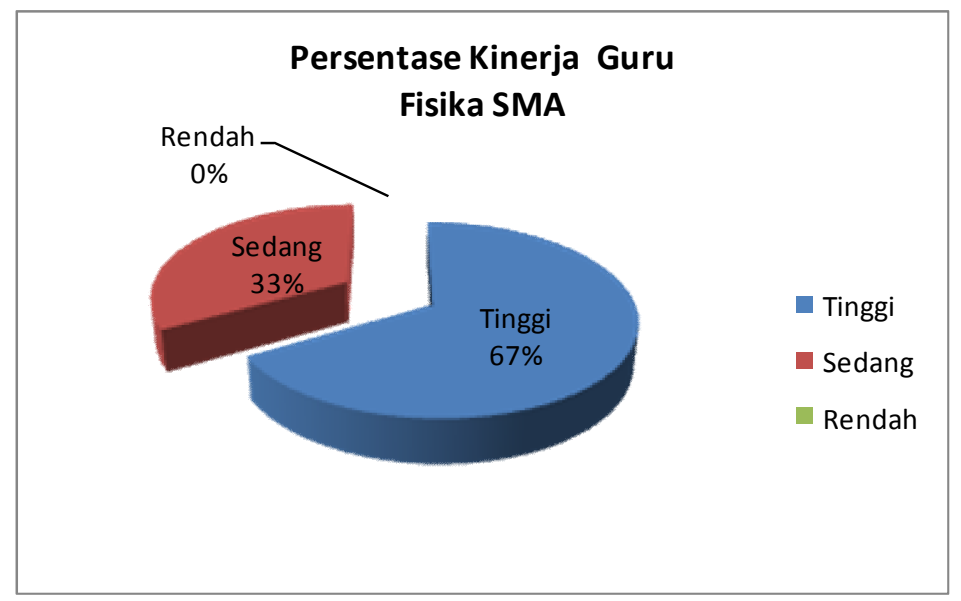

Gambar 2. Kinerja Guru-guru Fisika, SMA yang Sudah Lulus Sertifikasi

Untuk pelajaran Biologi, ditemukan sebanyak 76,5\% guru biologi tingkat kinerjanya dalam kategori tinggi, dan sebanyak 23,5\% guru biologi dalam kategori tingkat kinerjanya sedang. 


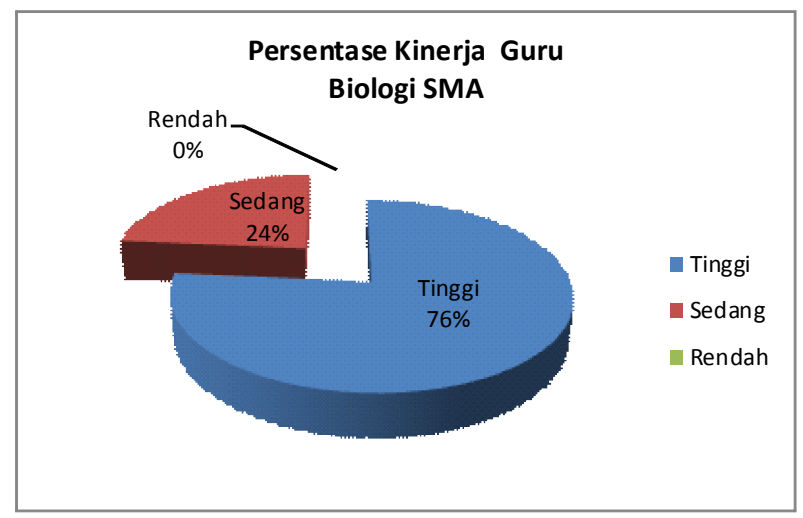

Gambar 3. Kinerja Guru-guru Biologi, SMA yang Sudah Lulus Sertifikasi

Selanjutnya, untuk mata pelajaran Kimia diperoleh hasil analisisnya, sebanyak 88,8\% guru kimia berada dalam kategori kinerjanya tinggi, dan hanya $11,1 \%$ guru kimia yang masih dalam kategori tingkat kinerja sedang. Jadi, urutan tingkat kinerja guru kinerja guru-guru yang berada dalam kategori tinggi adalah guru Kimia, Biologi dan Fisika.

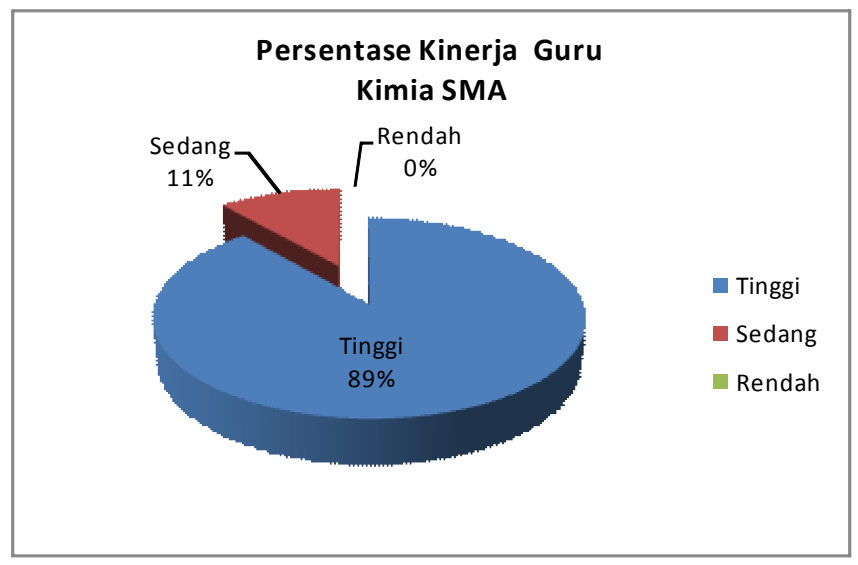

Gambar 4. Kinerja Guru-guru Kimia, SMA yang Sudah Lulus Sertifikasi 


\section{a. Komponen Strategi Pembelajaran}

Berdasarkan hasil analisis dari keseluruhan guru yang diteliti untuk komponen strategi pembelajaran ditemukan $8(22,8 \%)$ orang guru yang strategi pembelajarannya berada dalam kategori tinggi, ada sebanyak 26 $(74,3 \%)$ orang guru strategi pembelajarannya dalam kategori sedang, dan ada $1(2,8 \%)$ orang guru strategi pembelajarannya masih rendah. Jadi strategi pembelajaran guru-guru yang sudah lulus sertifikasi/telah menerima tunjangan profesi ketika mengajar belum maksimal.

Pada level mata pelajaran, untuk Fisika ada $3(33,3 \%)$ orang guru strategi pembelajarannya ada dalam kategori tinggi, 5 (55,5\%) orang guru strategi pembelajarannya dalam kategori sedang, dan ada $1(11,1 \%)$ orang guru strategi pembelajaannya dalam kategori rendah. Pada mata pelajaran Biologi, sebanyak $3(17,6 \%)$ orang guru strategi pembelajarannya dalam kategori tinggi, dan sebanyak $14(82,3 \%)$ orang guru strategi pembelajarannya dalam kategori sedang. Untuk pelajaran Kimia, sebanyak 2 (22,2\%) orang guru stategi pembelajarannya ada dalam kategori tinggi, dan sebanyak 7 $(77,7 \%)$ orang guru dalam kategori sedang. Hal ini menunjukkan bahwa masih banyak guru SMA pengajar Fisika, Biologi dan Kimia meski sudah tersertifikasi dan menerima tunjangan profesi namun penggunaan stategii pembelajarannya belum membaik.

\section{b. Komponen Penguasaan Materi}

Untuk komponen Penguasaan Materi, hasil analisis menunjukkan sebanyak $29(82,8 \%)$ orang guru ada dalam kategori tinggi, dan sebanyak 6 $(17,1 \%)$ orang guru dalam kategori sedang. Meski komponen penguasaan materi dapat dikatakan relatif baik, namun masih perlu ada upaya agar semua guru pengajar Fisika, Biologi, dan Kimia, khususnya yang tersertifikasi harus menguasai materi pelajarannya secara komprehensif.

Untuk mata pelajaran Fisika, didapati $7(77,8 \%)$ orang guru dalam kategori tinggi, dan sebanyak 2 (22,2\%) orang guru dalam kategori sedang. Pada mata pelajaran Biologi, diperoleh sebanyak 14 (82,3\%) orang guru sudah dalam kategori tinggi, dan sebanyak 3 (17,7\%) orang guru dalam kategori sedang. Selanjutnya, untuk pelajaran Kimia, diperoleh sebanyak 8 
$(88,9 \%)$ orang guru dalam dalam kategori tinggi, dan sebanyak $1(11,1 \%)$ orang guru yang dalam kategori sedang. Urutan prosentase penguasaan materi pelajaran adalah guru-guru Kimia, Biologi dan Fisika.

\section{c. KomponenPengelolaan Kelas}

Berdasarkan hasil analisis pada komponen Pengelolaan Kelas, diperoleh sebanyak $31(88,6 \%)$ orang guru pengelolaann kelasnya sudah dalam kategori tinggi, dan hanya sebanyak $4(11,4 \%)$ orang guru yang pengelolaan kelasnya kategori sedang. Dapat dikatakan pengelolaan kelas oleh guruguru tersertifikasi sudah baik.

Berdasarkan mata pelajaran, pada Fisika didapati sebanyak $6(66,6 \%)$ orang guru pengelolaan kelasnya sudah dalam kategori tinggi, dan sebanyak $3(33,3 \%)$ orang guru dalam kategori sedang. Pada guru Biologi,ada sebanyak $16(94,1 \%)$ orang guru pengelolaan kelasnya sudah dalam kategori tinggi, dan hanya $1(5,9 \%)$ orang guru saja yang pengelolaan kelasnya dalam kategori sedang. Pada mata pelajaran Kimia, ke semua guru Kimia $(100 \%)$ pengelolaan kelasnya dalam kategori tinggi. Urutan prosentase komponen pengelolaan kelas ketika mengajar adalah guru-guru Kimia, diikuti oleh guru Biologi, dan kemudian oleh guru Fisika.

\section{d. Komponen Komunikasi Guru dengan Siswa}

Berdasarkan hasil analisis, pada komponen komunikasi antara guru dan siswa didapati sebanyak $30(85,7 \%)$ orang guru komunikasinya dengan siswa sudah kategori tinggi, hanya ditemukan sebanyak $5(14,2 \%)$ orang guru yang komunikasinya dengan siswa kategori sedang. Secara keseluruhan dapat dikatakan komunikasi antara guru dan siswa sudah baik.

Untuk pelajaran Fisika, didapati sebanyak $6(66,6 \%)$ orang guru komunikasinya dengan siswa dalam kategori tinggi, dan sebanyak $3(33,3 \%)$ orang guru komunikasinya dengan siswa dalam kategori sedang. Pada pelajaran Biologi, didapati sebanyak $16(94,1 \%)$ orang guru komunikasinya dengan siswa dalam dalam kategori tinggi, dan hanya ada 1 (5,9\%) orang guru yang komunikasinya dengan siswa dalam kategori sedang. Selanjutnya, pada pelajaran Kimia, ditemukan $7(77,7 \%)$ orang guru komunikasinya 
dengan siswa dalam kategori tinggi, dan hanya ada 2 (22,2\%) orang guru yang komunikasinya dengan siswa pada tingkat kategori sedang. Ini menunjukkan bahwa urutan komunikasi antara guru dan siswa adalah guruguru Biologi, Kimia dan Fisika.

\section{e. Komponen Teknik Mengajar}

Untuk komponen Teknik Mengajar Guru, hasil analisisnya menunjukkan bahwa sebanyak 31 (88,6 \%) orang guru teknik mengajarnya dalam kategori tinggi, dan hanya sebanyak $4(11,4 \%)$ orang guru teknik mengajarnya dalam kategori sedang. Jadi, Teknik Mengajar guru-guru tersertifikasi secara umum sudah memadai.

Rincian untuk per mata pelajaran, untuk pelajaran Fisika, menunjukkan ada sebanyak $6(66,7 \%)$ orang guru teknik mengajarnya dalam kategori tinggi, dan ada sebanyak $3(33,3 \%)$ orang guru teknik mengajarnya dalam kategori sedang. pada mata pelajaran Biologi, didapati sebanyak $16(94,1 \%)$ orang guru teknik mengajar guru dalam kategori tinggi, dan hanya $1(5,9 \%)$ orang guru yang teknik mengajarnya dalam kategori sedang. Pada mata pelajaran Kimia, hasil analisisnya menunjukkan keseluruhan (100\%) guru Kimia teknik mengajarnya sudah dalam kategori tinggi. Urutan prosentase teknik mengajar guru adalah guru-guru Kimia, Biologi, dan Fisika.

\section{f. Komponen Penilaian Hasil Belajar Siswa}

Pada komponen penilaian hasil belajar siswa, hasil analisisnya menunjukkan sebanyak $11(31,4 \%)$ orang guru dalam kategori tinggi, sebanyak $23(65,7 \%)$ orang guru dalam kategori sedang, dan ada 1 (2,8\%) orang guru dalam kategori rendah. Komponen ini agak memprihatinkan, karena kebanyakan guru masih berada dalam kategori sedang. Jika dikaitkan dengan item dalam kuesioner, maka artinya para guru SMA pengajar pelajaran Fisika, Biologi dan Kimia tidak/jarang mengumumlan hasil pekerjaan terbaik siswa ketika melakukan penilaian kerja kelompok, dan tidak/jarang memberitahukan hasil PR/tugas-tugas siswa.

Untuk rincian menurut mata pelajaran, pada pelajaran Fisika ditemukan sebanyak $8(88,9 \%)$ orang guru dalam kategori sedang, dan $1(11,1 \%)$ 
orang guru dalam kategori rendah. Untuk pelajaran Biologi, didapati sebanyak $8(47,0 \%)$ orang guru penilaian hasil belajar siswa dalam kategori tinggi, dan sebanyak 9 (52,9\%) oang guru dalam kategori sedang. Sedangkan untuk pelajaran Kimia hanya ada $3(33,3 \%)$ orang guru dalam kategori tinggi dan sebanyak $6(66,6 \%)$ orang guru dalam kategori sedang.Secara keseluruhan komponen penilaian hasil belajar siswa ini perlu ada pembenahan.

\section{Kesimpulan}

Berdasarkan hasil analisis, dapat dikemukakan beberapa kesimpulan terkait tingkat kinerja guru yang sudah lulus sertifikasi, yaitu: (1) kinerja guru SMA yang mengajar Fisika, Biologi, Kimia belum seluruhnya berkinerja tinggi, meski mereka sudah lulus sertifikasi dan sudah menerima tunjangan profesi, (2) Kinerja guru Kimia relatif lebih baik dari pada kinerja guru Biologi dan guru Fisika, (3) Ada dua komponen kinerja yang masih memprihatinkan, yaitu komponen penilaian hasil belajar siswa dan komponen strategi pembelajaran, (4) Komponen penilaian hasil belajar siswa masih memprihatinkan karena tidak sseorangpun guru dalam komponen ini berada dalam kategori kinerja tinggi, (5) Komponen strategi pembelajaran meski sudah ada guru yang berada dalam kategori kinerja tinggi, namun persentasenya masih kecil dibandingkan dengan guru yang berada dalam kategori kinerja sedang.

\section{Saran}

Berdasarkan kesimpulan di atas, maka saran-saran yang diajukan adalah: diperlukan adanya monitoring dan evaluasi yang ketat terhadap kinerja guru, khususnya kinerja guru yang sudah lulus sertifikasi/menerima tunjangan profesi Dinas pendidikan baik dinas pendidikan provinsi maupun dinas pendidikan kabupaten/kota dapat melakukan hal itu.

Perlu ada perubahan dalam menetapkan guru untuk disertifikasi. Sebaiknya, pola penunjukan guru untuk sertifikasi tidak didasarkan kepada kriteria-kriteria usia guru, pangkat atau masa kerja guru, tetapi kepada guruguru yang berprestasi. Untuk tujuan ini, diperlukan suatu mekanis tertentu. 
Penelitian evaluasi kinerja guru sebaiknya dilanjutkan pada skala yang lebih luas. Artinya, penelitian evaluasi kinerja guru perlu dilakukan pada semua tingkat satuan pendidikan, juga pada semua guru bidang studi di seluruh wilayah Indonesia, khususnya guru-guru yang sudah lulus sertifikasi/menerima tunjangan profesi.

\section{Daftar Pustaka}

Anderson, Scarvia B, et al .(!975).Encyclopedia of educational evaluation. California: Jossey-Bass Inc. Publisher.

Azwar, Saifuddin. (2003).Penyusunan skala psikologis, Yogyakarta: Pustaka Pelajar.

Caroll, Stephen J., Tosi, Henry L.(1977).Organizational behavior, Chicago St: Clair Press.

Djaali\&Muljono,Pudji.(2008). Pengukuran dalam bidang pendidikan.Jakarta: Grasindo.

Gable, Robert K. (1986). Instrumen development in affective domain. Boston:Kluwer-Nijhoff Publishing.

Gibson, L, Incevich,John M.\& Donnelly.(1985). Organization. Texas: Busines Publicatiobs, Inc.

Gronlund, Norman E \& Robert L. Linn.(1985).Measurement andevaluation in teaching. New York: Macmillan PublishingCompany.

Hadi, Sutrisno.(1986).Metodologi research. Jilid 2, Yogyakarta: Yayasan Penerbit Fakultas Psikologi UGM.

Miller, Richard J. (1975). Developing programs for faculty evaluation. San Fransisco: Jessey-Bass Publishers. 
Mitchell, Terence R. (1982).People in organizations understanding their behavior. New York: McGraw Hill,Book Company.

MuhammadAs"ad. (1995).Psikologi industri .Yogyakarta: Liberti,.

Muhammad, Farouk dan Djaali. (2005). Metodologi penelitian sosial, Jakarta: Restu Agung

Prowirosentono, Suyadi. (1999). Kebijakan kinerja karyawan.Yogyakarta: BPFE,

Reddy, R. S. (1998).Principles and practices of teacher education. New Delhi: Rajat Publication.

Riyanto, Astin.(2003).Proses belajar mengajar efektif di perguruan tinggi.Bandung: Yapemdo

Santoso, Singgih.(2003).SPSS statistik multivariate. Jakarta: PT Elex Media Komputido.

Soekartawi. (1995).Meningkatkan efektivitas mengajar, Jakarta:Pustaka Jaya.

Sumiyati.(2005). Hubunganantara kreativitas, kecerdasan emosional, danpenguasaan materi dengan kinerja guru kimia SMU di DKI, Sinopsis Disertasi. PPs Universitas Negeri Jakarta.

Suryabrata, Sumadi. (2000).Pengembangan alat ukur psikologis.Yogyakarta: Andi Offet.

Usman, Mohd.Uzer. (2003).Menjadi guru profesional, Bandung: PT.Remaja Rosdakarya. 